DR HAB. AGNIESZKA SZUDAREK, PROF. USZ

Uniwersytet Szczeciński

\title{
Ortrud Wörner-Heil, Adelige Frauen als Pionierinnen \\ der Berufsbildung. Die ländliche Hauswirtschaft \\ und der Reifensteiner Verband, University Press Kassel, \\ Kassel 2010, ss. 488, ISBN 978-3-89958-904-7
}

W niemieckiej nauce historycznej od dłuższego już czasu można obserwować wzrost zainteresowania badaczy problematyka związana $z$ sytuacja szlachty $\mathrm{w}$ okresie transformacji społeczno-gospodarczych oraz politycznych XIX i początku XX wieku. Przechodzenie od społeczeństwa agrarnego do społeczeństwa przemysłowego oznaczało $z$ jej perspektywy utratę dotychczasowych przywilejów politycznych, gospodarczych i społecznych. W dobie industrializacji, gospodarki kapitalistycznej, postępu technicznego i demokratyzacji życia politycznego szlachta, mająca w Niemczech do 1919 r. status stanu społecznego, powoli stawała się reliktem przemijającego świata. Nie oznacza to jednak, że nie podejmowała działań, majacych na celu utrzymanie swojej dotychczasowej pozycji, zwłaszcza że wciąż cieszyła się specjalnymi względami w monarchii Hohenzollernów. Wśród publikacji na ten temat do niedawna brakowało prac przedstawiajacych wyżej wspomniana problematykę $z$ perspektywy szlachcianek, mimo że niektóre $z$ nich bardzo boleśnie odczuwały zachodzące zmiany. Oznaczały one bowiem przede wszystkim konieczność przemodelowania ich dotychczasowego stylu życia oraz zadań, jakie miały realizować w rodzinie i w społeczeństwie. Opublikowana w Kassel 
w 2010 r. praca Ortrud Wörner-Heil pt. Adelige Frauen als Pionierinnen der Berufsbildung. Die ländliche Hauswirtschaft und der Reifensteiner Verband stanowi pierwszą monografię, poświęconą $\mathrm{w}$ całości tej problematyce. Nie pretenduje ona oczywiście do kompleksowego omówienia tego złożonego zagadnienia, ale wskazuje na szereg przyczyn, jakie wpłynęły na konieczność wprowadzenia nowych elementów w modelu edukacji dziewcząt, należących do tego stanu. Rozważania te prowadza Autorkę do postawienia tezy, że szlachcianki były pionierkami kształcenia zawodowego $\mathrm{w}$ profesjach zwiazanych $\mathrm{z}$ kobiecym gospodarstwem domowym na obszarach wiejskich. W tym też kontekście omawia ona Związek $z$ Reifenstein (Reifensteiner Verband), organizacją powołująca do życia i zrzeszająca w całych Niemczech od końca lat 90. XIX wieku szkoły gospodarstwa wiejskiego dla kobiet, należących do wyższych warstw społecznych, zwracając szczególną uwage na okoliczności powstania Zwiąku i pierwszych szkól, w tym zasady ich funkcjonowaniaํ. Poświęca również sporo miejsca biografiom szlachcianek, które odegrały kluczowa rolę w dziejach tego typu szkolnictwa w Niemczech. Biografie te nie tylko tworza cenny kontekst dla omawianych procesów, ale także sa pretekstem do pokazania $z$ jednej strony przemian zachodzacych w dziejach tych elitarnych szkół (ze szczególnym uwzględnieniem okresu do lat 50. XX wieku, mimo iż niektóre $z$ nich działały do 1990 r.), z drugiej zaś podkreślenia, że edukacja w tych placówkach przygotowywała kobiety do odgrywania wiodacej roli nie tylko w lokalnych, wiejskich społecznościach. Takie ujęcie tematu zaowocowało specyficzna struktura pracy. Rozprawa, poprzedzona krótką przedmową Heide Wunder, znanej niemieckiej badaczki, zajmujacej się dziejami kobiet i niemieckiej szlachty, składa się ze wstępu, sześciu rozdziałów wyodrębnionych na podstawie kryterium rzeczowego, spisu ilustracji, bibliografii, indeksu osobowego i notki o autorce.

1 Szkołom dla dziewcząt prowadzonym przez wspomniana organizację poświęcona była wcześniejsza publikacja Ortrud Wörner-Heil, Frauenschulen auf dem Lande. Reifensteiner Verband 1897-1997, Kassel 1997. 
Kluczowe znacznie ma jednak rozdział pierwszy, najobszerniejszy (s. 41-180), gdyż to w gruncie rzeczy w nim zawarte zostały wszystkie ustalenia badawcze Ortrud Wörner-Heil, zwiazane $z$ podjętym tematem. Jego tytuł: Adelige Frauen, Berufsbildung und Frauenbewegung (Szlachcianki, kształcenie zawodowe i ruch kobiecy) zwraca uwage na trzy najistotniejsze kwestie, pozwalajace zrozumieć, w jakich okolicznościach doszło na początku XX wieku do wprowadzenia w Niemczech nowego elementu we wzorcu osobowym szlachcianki, mianowicie fachowego przygotowania do prowadzenia wiejskiego gospodarstwa domowego. Pozostałe rozdziały poświęcone zostały szerokiemu, erudycyjnemu nakreśleniu biografii kilku szlachcianek, które związane były ze wspomnianym typem szkolnictwa jako jego twórczynie lub wybite absolwentki.

Kluczowe znacznie dla przedstawionego w publikacji problemu ma postać Idy von Kortzfleisch, o której Autorka pisze w rozdziale pierwszym i której poświęca też cały rozdział drugi (Bildungsreformerin in der Moderne. Ida von Kortzfleisch (1850-1915), s. 181-254). Ida była szlachcianka urodzona w 1850 r. w Prusach Wschodnich, która wiosna 1894 r. zamieściła w jednej z niemieckich gazet artykuł, przedstawiajac $\mathrm{w}$ nim po raz pierwszy swoja koncepcję kształcenia gospodarczego dziewcząt. Jej pomysł, rozwijany w kolejnych publikacjach, był według Ortrud Wörner-Heil nowatorski $z$ dwóch powodów. W pierwszej kolejności dlatego, że postulował edukację zawodowa dziewczat $z$ wyższych warstw społeczeństwa jako drogę do samodzielności i niezależności ekonomicznej. Nauka zawodu i praca na własne utrzymanie nie mieściły się jednak w obowiąujacym modelu wychowawczym córek pochodzacych $z$ rodzin szlacheckich oraz wykształconego lub/i zamożnego mieszczaństwa. Przygotowywane były one bowiem do roli żony, matki, pani domu, damy prowadzacej mniej lub bardziej aktywne życie towarzyskie. Ida von Kortzfleisch jednak nie kwestionowała spełniania się kobiet w małżeństwie, chciała jedynie, by wchodząc w dorosłe życie, były lepiej przygotowane do trudów codzienności oraz miały alternatywę w postaci aktywności zawodowej. Możliwość zarobkowania była o tyle istotna, że wiele kobiet 
$z$ wyższych warstw społeczeństwa $z$ różnych względów nie wychodziło za mąż i po śmierci najbliższych pozostawało bez zabezpieczenia finansowego, wiodąc życie - jak określała to Ida von Kortzfleisch - uprzywilejowanej żebraczki. Postulat ten był również jednym $z$ głównych haseł niemieckiego ruchu kobiecego, stąd też nie może dziwić, że początkowo spotkał się $z$ krytyka. Tym, co zaważyło, iż ostatecznie doczekał się realizacji i został przynajmniej przez część szlachty zaakceptowany był aspekt ideologiczny, czyli drugi element, który według Autorki publikacji świadczy o znaczeniu koncepcji Idy von Kortzfleisch. Szlachcianka ta uważała bowiem, że niewykorzystanie potencjału drzemiacego $\mathrm{w}$ kobietach to marnotrawstwo $\mathrm{i}$ one również powinny właczyć się w budowę potęgi i siły ekonomicznej Cesarstwa. Ich praca miała być służbą państwu, dziełem narodowym, odpowiednikiem służby wojskowej mężczyzn. Obszar aktywności zawodowej nie był też przypadkowy, gdyż w grę wchodziła wyłącznie profesjonalizacja zajęć kobiecych w gospodarstwie wiejskim. Dzięki fachowemu przygotowaniu i wyposażeniu w wiedzę, uwzględniająca najnowsze osiagnięcia techniczne oraz postęp w zakresie upraw i hodowli zwierzat, miały być one nie tylko lepszymi paniami na włościach, ale także edukować w tym zakresie chłopki i tym samym służyć ojczyźnie. Teoretyczne i praktyczne przygotowanie do pracy $\mathrm{w}$ wiejskim gospodarstwie domowym uważała za przejaw patriotyzmu, sposób na manifestację uczuć narodowych. Ortrud Wörner-Heil słusznie uznaje, że przywołane poglądy stanowią doskonały przykład ilustrujący wprowadzone do dyskursu naukowego przez brytyjskiego badacza Michaela Billinga pojęcia banalnego nacjonalizmu, oznaczającego przypominanie i utrwalanie tożsamości narodowej przez różne czynności i praktyki życia codziennego.

Program Idy von Kortzfleisch nie był skierowany wyłącznie do szlachcianek, ale - jak w kolejnych partiach narracji wykazała Autorka rozprawy - to właśnie kobiety należące do tego stanu, odgrywały wiodąca rolę $\mathrm{w}$ jego realizacji, tj. tworzeniu sieci szkół kształcacych w zakresie wiejskiego gospodarstwa domowego. To one również najczęściej stały na czele zarządu Związku z Reifen- 
stein oraz stanowiły liczna grupę wśród dziewczat, podejmujacych kształcenie $\mathrm{w}$ podlegających mu placówkach. Autorka nie uchyla się od wyjaśnienia tego stanu rzeczy, podkreśla jednak przede wszystkim, że poparcie przez część szlachty koncepcji Idy von Kortzfleisch miało ogromne znaczenie, gdyż wiąało się $z$ przełamaniem stanowych uprzedzeń dotyczacych zawodowego kształcenia córek $z$ rodzin szlacheckich. Zwrot ten był możliwy, gdyż w koncepcji tej szlachta odnalazła bliskie jej elementy, takie jak: powiązanie $z$ ziemia, służbę na rzecz państwa, dobroczynność czy opiekę nad mieszkańcami wsi. Wyedukowane żony i córki właścicieli ziemskich miały być koryfeuszkami postępu na wsi, dawać przykład, ale i szkolić np. w zakresie nowych metod stosowanych w mleczarstwie, sadownictwie czy hodowli drobiu. Taka postawa miała pomóc szlachcie w utrzymaniu przywódczej roli na obszarach wiejskich.

Pierwsza szkoła gospodarstwa wiejskiego dla kobiet została utworzona w Hesji, w Nieder-Ofleiden w 1897 r. Organem założycielskim było powstałe rok wcześniej stowarzyszenie, które następnie zmieniło nazwę na Związek $z$ Reifenstein (Reifensteiner Verband). W ciagu kolejnych lat (Związek działa nadal, chociaż nie prowadzi już żadnych placówek) otworzył on w całych Niemczech piętnaście kolejnych placówek tego typu, połączonych niekiedy z seminariami dla nauczycielek, natomiast nad około pięćdziesięcioma podobnymi przejął nadzór. Nie bez znaczenia było tu poparcie dworu i patronat cesarzowej, gdyż koncepcja Idy von Kortzfleisch doskonale wpisywała się w politykę mobilizacji całego społeczeństwa niemieckiego wokół imperialistycznej wizji cesarza Wilhelma II. Po I wojnie światowej nie od razu udało się wyeliminować to promonarchistyczne nastawienie, co wywoływało niekiedy konflikty kierownictwa szkół z władzami. Nie wszystkie placówki chciały też realizować cele stawiane przed tego typu instytucjami przez narodowych socjalistów. W sumie po 1945 r. funkcjonowało ich już tylko siedem, ale kolejne lata jeszcze zmniejszały tę liczbę. Do lat 90. XX wieku w szkołach Związku $z$ Reifenstein wykształciło się ok. 90 tys. kobiet, $z$ czego 40 tys. w 15 placówkach założonych przez tę organizację. Uczennice szkół, nazwane 
jeszcze przez Idę von Kortzfleisch angielskim słowem Maiden ${ }^{2}$, czyli dziewczęta, kobiety niezamężne, były kształcone w dziesięciu dziedzinach: pracach w kuchni, pracach domowych, bieliźniarstwie, robótkach, zarzadzaniu gospodarstwem, prowadzeniu ksiag, ogrodnictwie, hodowli drobiu, mleczarstwie. W programie miały również zajęcia ruchowe. Młode kobiety przygotowywały się $\mathrm{w}$ ten sposób nie tylko do prowadzenia własnego gospodarstwa domowego, ale $\mathrm{w}$ ciagu roku zyskiwały uprawnienia do pracy $\mathrm{w}$ zawodach, np. zarządczyni $\mathrm{w}$ majątku ziemskim, sekretarki $\mathrm{w}$ administracji gospodarstwa wiejskiego, nadzorczyni w mleczarni, kierowniczek jadłodajni, pracownic domów opieki, klinik, fundacji. Nauka trwała kolejne miesiace (do 2 lat), jeżeli uczennica chciała mieć certyfikat nauczycielki w zakresie wymienionych zajęć gospodarczych.

Wyniki badań Ortrud Wörner-Heil nie tylko korygują obraz szlachty przełomu XIX i XX wieku, ale również stanowiącego niemiecką specyfikę konserwatywnego nurtu ruchu kobiecego. Jak już wykazała Andrea Süchting-Hänger ${ }^{3}$ nurt ten, mający podobnie jak dwa pozostałe: umiarkowany i radykalny - liczne grono zwolenniczek, co prawda nie był jednolity programowo, ale opowiadał się także za profesjonalizacją zajęć kobiecych w gospodarstwie domowym, a następnie przenoszeniem ich $\mathrm{w}$ sferę publiczna, jako profesji wykonywanych zarobkowo. Dotąd zajmowano się jednak tylko miastami, nie zauważając podobnych działań, majacych miejsce na obszarach wiejskich. Niniejsza publikacja wypełnia więc tę lukę. Autorka zwraca także uwagę, że na upowszechnienie profesjonalizacji zajęć kobiecych w wiejskim gospodarstwie domowym wpłynęła działalność stowarzyszeń wiejskich gospodyń domowych (Landwirtschaftliche Hausfrauenvereine), które zainicjowała Elizabeth Boehm w Prusach Wschodnich, w 1898 r. Nie bez znaczenia była również współpraca podjęta

\footnotetext{
2 Słowo Maid zyskało niebawem też i inną wykładnię. Tworzyć go miały pierwsze litery słów określających katalog cnót uczennic, czyli Mut, Ausdauer, Idealismus i Demut, tj. odwaga, wytrwałość, idealizm i pokora.

3 A. Süchting-Hänger, Das „Gewissen der Nation”: nationales Engagement und politisches Handel konservativer Frauenorganisationen 1900 bis 1937, Düsseldorf 2002 .
} 
przez Zwiazek $z$ Reifenstein ze Stowarzyszeniem Szlachty Niemieckiej (Deutsche Adelsgenossenschaft), które - chcąc pomóc kobietom ze zubożałych rodzin szlacheckich - promowało koncepcję Idy von Kortzfleisch.

Dzieje szkół podlegających Związkowi czytelnik można śledzić poprzez kolejne, biograficzne rozdziały rozprawy. Ortrud WörnerHeil przybliża w nich życie i działalność: Elly Gans Edle Herrin zu Putlitz (1869-1924) - absolwentki szkoły w Nieder-Ofleiden (s. 255-303), Ruth Steiner z domu von Kalckreuth (1879-1955) absolwentki szkoły w Reifenstein i Obernkirchen, działaczki ruchu gospodyń wiejskich i wydawczyni fachowego czasopisma dla mieszkanek wsi (s. 305-369), Agnes baronówny von Dincklage (1882-1962) - absolwentki szkoły w Obernkirchen, a następnie jej wieloletniej dyrektorki (s. 371-398) oraz Elsbeth von Oppen 1904-1978 - absolwentki szkoły w Mieszkowicach, w latach 1924-1962 nauczycielki pracujacej w różnych szkołach Związku $z$ Reifenstein (s. 399-451). Przy okazji warto zwrócić uwage na występujące w publikacji wątki polskie. Mianowicie kilka szkół wiejskiego gospodarstwa domowego powstało na terenach znajdujących się obecnie $w$ granicach naszego państwa. Dwie $z$ nich założono $\mathrm{w}$ zadłużonych majątkach ziemskich, przejętych przez Komisję Kolonizacyjną. Pierwszym $z$ nich był Mroczeń w Wielkopolsce, gdzie w latach 1904-1919 działała szkoła gospodarstwa domowego dla kobiet (Wirtschaftliche Frauenschule Maidburg), przeniesiona w związku ze zmiana granic po I wojnie światowej na Śląsk, do Piławy Górnej, gdzie funkcjonowała do zakończenia II wojny światowej (Wirtschaftliche Frauenschule Maidhof in Schlesien). Drugim był Szczerpięcin (Wirtschaftliche Frauenschule in Westpreußen Scherpingen), leżący między Tczewem a Gdańskiem, gdzie szkoła działała od 1908 do 1929 r., a więc także wtedy, gdy miejscowość ta znalazła się w granicach II Rzeczpospolitej. Inne „polskie” placówki podlegające Zwiąkowi z Reifenstein założone zostały: w 1914 r. w Mieszkowicach (Bärwalde), obecne województwo zachodniopomorskie oraz w 1925 r. w Nowej Wsi Ełckiej (Neuendorf bei Lyck), obecne województwo warmińsko-mazurskie. Warto podkreślić te epizody w dziejach oświaty 
w wymienionych miejscowościach, gdyż nie wspomina się o nich w polskiej literaturze przedmiotu. Tym bardziej, że funkcjonowanie elitarnych szkół gospodarstwa wiejskiego dla kobiet, promujących postęp w rolnictwie, prowadzacych wzorcowe uprawy i hodowle nie mogło nie wpływać na okolicznych mieszkańców. Szkoły pośredniczyły też w znalezieniu pracy, prowadziły świetlice dla miejscowych dzieci i młodziė̇y. Były więc tętniącymi życiem ważnymi ośrodkami oświaty rolniczej, ale także miejscami propagowania nowego modelu kobiety zaangażowanej narodowo.

Omawiana publikacja powstała w oparciu o szeroka bazę źródłowa, obejmujaçą zarówno źródła archiwalne, jak i źródła drukowane. W pierwszym przypadku to przede wszystkim zespół akt Związku $z$ Reifenstein, przechowywany w archiwum w dolnosaksońskim Bückeburg. W drugim zaś to szereg publikacji poczawszy od prasy, przez wydawnictwa publicystyczne, po wspomnienia i pamiętniki, a nawet literaturę piękną. Trudno orzec, czy kwerenda w berlińskim Geheimes Staatsarchiv Preußischer Kulturbesitz pomogłaby Autorce w badaniach, niewatpliwie jednak akta pruskich urzędów centralnych na pewno pozwoliłyby spojrzeć na omawiana problematykę $z$ szerszej perspektywy i uchroniły od zarzutu jednostronności. Badaczce udało się dotrzeć do najważniejszych prac na temat szlachty niemieckiej i kobiet należących do tego stanu, chociaż dostrzec można brak publikacji Christy Diemel pod tytułem Adelige Frauen im bürgerlichen Jahrhundert. Hofdamen, Stiftsdamen, Salondamen 18001870 (Frankfurt nad Menem 1998).

Niedosyt budzi również liczba prac dotyczących przemian gospodarczych, reform edukacji czy przemian politycznych w Niemczech, które mogłyby stworzyć kontekst dla poruszanej problematyki. Poważnym uchybieniem jest natomiast budowa bibliografii. Autorka co prawda na początku wymieniła źródła archiwalne, ale po nich odnotowała kolejno wszystkie wykorzystane przez siebie materiały zarówno źródłowe, jak i opracowania naukowe, wprowadzając w ten sposób ogromny chaos. Dopiero skrupulatna i czasochłonna analiza pozwala ocenić zakres przeprowadzonej kwerendy. 
Mimo tych warsztatowych uchybien, które jednak nie dotyczą strony metodologicznej przeprowadzonych badań praca Ortrud Wörner-Heil odkrywa przed czytelnikiem nowy wymiar emancypacji kobiet w Niemczech. Wydaje się jednak, że Autorka zbyt mocno podkreśla to, że Zwiazek z Reifenstein był pierwsza platformą współpracy szlachcianek i działaczek mieszczańskich. Trzeba bowiem pamiętać o powstających pod patronatem królowej Prus (po 1871 r. cesarzowej) od lat sześćdziesiątych XIX wieku Patriotycznych Stowarzyszeń Kobiecych (Vaterländische Frauenverein). Pokryły one zwarta siecią całe Niemcy i przed wybuchem I wojny liczyły ponad 500 tys. członkiń, propagując również kształcenie zawodowe kobiet (np. na pielęgniarki, opiekunki czy wychowawczynie dzieci). Niewatpliwie jednak to właśnie Zwiazek $z$ Reifenstein rozwiną nowy model szkoły zawodowej dla kobiet $z$ elit szlachecko-mieszczańskich, a poprzez to także wpisał się $\mathrm{w}$ postulaty mieszczańskiego ruchu kobiecego. Zbieżność programowa była zresztą dla współczesnych oczywista. W niektórych partiach narracji Autorka nieco nadinterpretowuje tę sytuację. Stwierdza bowiem, że w literaturze przedmiotu funkcjonuje nie do końca prawdziwy pogląd o polaryzacji świata szlachty i mieszczaństwa. Przedstawione przez nia przykłady kooperacji kobiet $z$ obu kręgów maja temu przeczyć i wskazywać, że część szlachty była jednak skłonna włączyć nowe wartości (kształcenie zawodowe i prace zarobkowa córek) do przekazywanego $z$ pokolenia na pokolenie modelu wychowawczo-edukacyjnego szlachcianek. Czy jednak włączenie tych nowych elementów nie stało się koniecznością? Widoczne coraz bardziej w II połowie XIX wieku ubożenie wielu rodzin szlacheckich, duży odsetek szlachcianek pozostajacych w stanie panieńskim, długie kolejki oczekujących na przyjęcie do fundacji opiekuńczych dla kobiet, setki próśb o zapomogi czy pensje wysyłane do różnych funduszy, udzielających wsparcia kobietom $z$ elit, pozostawionym bez środków do życia, nie pozostawiało wyboru. Kształcenie zawodowe dziewczat na przełomie XIX i XX wieku stawało się koniecznościa, forma zabezpieczenia przyszłości. Akceptacja tego stanu przychodziła jednak szlachcie $z$ trudnościa, stąd tak obfita publicystyka na ten temat, skiero- 
wana właśnie do niej. Szlachta musiała się zmienić, co jednak nie oznacza, że zostały zlikwidowane czy ograniczone bariery między nią a mieszczaństwem. Zwłaszcza konserwatywna szlachta wschodnich prowincji Niemiec miała trudności z oswojeniem tego signum temporis. Wystarczy spojrzeć na lokalizację szkół Związku z Reifenstein. W znakomitej większości znajdowały się one w środkowych Niemczech. Na całym agrarnym Wschodzie, łącznie z prowincja poznańska, powstały do $1918 \mathrm{r}$. tylko trzy!

Innym elementem, który zwraca uwagę, jest brak cezur chronologicznych $\mathrm{w}$ tytule pracy. O ile cezurę początkową należy wiązać $z$ działalnością Idy von Kortzfleisch, o tyle końcowa wydaje się problematyczna. Autorka postawiła sobie bowiem za cel ukazanie roli szlachcianek $\mathrm{w}$ narodzinach nowego typu szkolnictwa zawodowego dla kobiet i włączania się ich w działania emancypacyjne, a więc dążenia kobiet do niezależności i samodzielności ekonomicznej. Zasadne byłoby więc określenie, do kiedy działalność ta ma - jak Autorka zaznaczyła w tytule pracy - charakter pionierski. $Z$ narracji można wnosić, iż kończy się on w latach dwudziestych XX wieku, kiedy nowa sytuacja polityczna, zmiany w obyczajowości, edukacji i prawie wymuszaja nowe podejście do sytuacji kobiet w państwie i społeczeństwie. Wskazanie cezury końcowej pozwoliłoby jednak uniknać pewnego dyskomfortu wynikającego $\mathrm{z}$ tego, że Autorka w swoich rozważaniach dochodzi do połowy XX wieku, ale informacje dotyczace okresu po 1919 r. sa coraz bardziej ogólne.

Odczuwalny jest również w publikacji brak aspektu porównawczego. Na podstawie lektury nie wiadomo, czy pomysł Idy von Kortzfleisch miał jakieś wzorce czy odpowiedniki w innych państwach europejskich. Można nawet odnieść wrażenie, że była to koncepcja na wskroś nowatorska. Wystarczy jednak przyjrzeć się chociażby sytuacji na przełomie wieków na ziemiach polskich (działalność Jadwigi z Działyńskich Zamoyskiej, Jadwigi Dziubińskiej czy Aleksandry Bąkowskiej), by stwierdzić że rozwijająca się wówczas edukacja rolnicza obejmowała swoim zasięgiem również kobiety i obudowana hasłami patriotycznej odnowy narodu stanowiła jedna $z$ cech epoki. Powstające $w$ Niemczech szkoły dla 
dziewcząt skupione $\mathrm{w}$ Związku $\mathrm{z}$ Reifenstein stanowiły więc niemiecki odpowiednik tych tendencji, dostosowany do potrzeb wilhelmińskiej Rzeszy.

Powyższe uwagi nie umniejszaja jednak ogromnego wkładu, jaki praca Ortrud Wörner-Heil wniosła w rozpoznanie nieporuszanych dotąd, bądź jedynie sygnalizowanych, kwestii dotyczacych sytuacji niemieckich szlachcianek na przełomie XIX i XX wieku. Panoramiczne omawianie problemu i biografie (a nie dzieje szkół), stanowiące integralną część rozprawy, pozwalają czytelnikowi nie tylko rozeznać się w specyfice ruchu kobiecego w Niemczech (nurt konserwatywny i jego powiazanie $z$ państwem), ale także poznać świat szlachty niemieckiej i trudności, z jakimi musiała się zmagać u progu nowoczesności.

\section{Bibliografia}

Süchting-Hänger A., Das „Gewissen der Nation”: nationales Engagement und politisches Handel konservativer Frauenorganisationen 1900 bis 1937, Düsseldorf 2002, ISBN 3-7700-1613-0.

Wörner-Heil O., Frauenschulen auf dem Lande. Reifensteiner Verband 1897-1997, Kassel 1997, ISBN 3-9260-6812-4. 